\title{
HOGYAN TOVÁBB CSALÁDI VÁLLALKOZÁSOK? - CSALÁDI VÁLLALKOZÁSOK UTÓDLÁSI JELLEMZÖI ÉS NEHÉZSÉGEI
}

\begin{abstract}
A kisvállalkozások szervezeti felépítésére jellemző a döntések és az irányítás központosulása. A vállalkozás növekedésével a vezető túlterheltté válik, egymaga nem képes minden funkciót megfelelően ellátni, át kell adni feladatot, hatalmat. $A$ túlterheltség feloldása az utódlás szempontjából még hangsúlyosabbá válik, hiszen a vezetőnek egy új, eddig ismeretlen kihívással kell szembenéznie, ami idő- és energiaigényes munka. A sikeres utódlás a vállalkozás életében kulcsfontosságú kérdés, hiszen az utódlás egy egyszeri feladata a vezetőnek, és korábbi tapasztalatokkal ezen a téren nem rendelkezik. A szerzők kutatási fókuszában a vizsgált vállalkozások utódlási folyamatainak feltérképezése volt, azok jellemzőinek és nehézségeinek feltárása. Magyarországon napjainkban az utódlás kérdése egyre több vállalkozást érint, ezért az átadási folyamat vizsgálata ezeknél a szervezeteknél kiemelt jelentőségű. A kutatás során esettanulmány módszert alkalmaztak, melynek keretében öt családi vállalkozást vizsgáltak meg. Az eredmények rámutattak azokra a főbb átadási és utódlási jellemzőkre és nehézségekre, amelyek speciálisan a vizsgált magyar vállalkozásokra jellemzőek. A kutatás eredményei alapján a lehetséges válaszok megfogalmazása is megtörtént az azonosított problémákra.
\end{abstract}

Kulcsszavak: utódlás, utódlási modellek, családi vállalkozások

A családi vállalkozások meghatározó szereplői a gazdasági életnek a világ minden táján. Európában a vállalkozások több mint $60 \%$-át a családi vállalkozások adják. Ezeknek a vállalkozásoknak a sikeressége az ország sikerét is jelentősen befolyásolja - gondoljunk csak az ország GDP-jéhez való hozzájárulásukra, vagy a munkahelyteremtő képességükre. Tevékenységük és az őket érő kihívások vizsgálata éppen ezért rendkívül fontos a vállalkozások különbözö életszakaszaiban (Vágány et al., 2016). Kiemelkedően fontos tehát, hogy a lehető legtöbbet megtudjuk a családi vállalkozások működéséről, helyzetéről és nem utolsó sorban az utódlási folyamatukról. A családi vállalkozások átadásáról és magáról az utódlási folyamatról azonban egyelöre keveset tudunk Magyarországon (Mosolygó et al., 2018). Mindezekből kifolyólag a hazai családi vállalkozások fogalmának meghatározása nehéz feladat. Definíciók sokasága született, melyek nem adnak egységes fogalommeghatározást. A definíciók a család tulajdonjogát és a vállalatirányításban való részvételt helyezik a középpontba. A meghatározások gyakran jellemzik a családi vállalkozásokat egyértelműen kisvállalkozásokként, holott ezek a vállalkozások létezhetnek minden vállalkozási méretben (Mandl, 2008). Az egységesség hiánya sokszor problémát jelent a vállalkozások számának pontos meghatározásában, valamint a különbözö kutatások összehasonlíthatóságában.

Az Európai Unió KKV-politikájában az alábbi meghatározás szerepel (European Comission, 2009): Méretük szerint családi vállalkozásnak tekinthető az egyéni vállalkozástól kezdve a nagy nemzetközi vállalat is; amelyben a döntési jogok többsége azon természetes személyek kezében van, akik a vállalatot alapították, vagy azon természetes személyek kezében van, akik a vállalat eredeti tőkéjét megvásárolták, vagy az ő házastársaik, szüleik, gyermekeik, illetve azok közvetlen örököseinek kezében van; a döntési jog többségét közvetve vagy közvetlen módon gyakorolják; a család vagy a rokonság minimum egy tagja formálisan részt vesz a vállalat vezetésében; a tőzsdén szereplő vállalatok akkor számítanak családi vállalatnak, ha a vállalatot alapító vagy megvásárló személy, vagy annak családja, illetve utódai a határozathozatali jogok legalább 25\%-a felett rendelkeznek az eredeti tőke feletti rendelkezésük alapján.

Magyarországon a mikrovállalkozások 95\%-át, a közép- és nagyvállalatok 20\%-át adják a családi vállalkozások. A foglalkoztatás területén is jelentős szerepük van, a foglalkoztatottak 45-50\%-a a családi tulajdonú cégeknél dolgozik. A hazai GDP 50-60\%-át termelik meg ezek a vállalkozások (Nagy - Tobak, 2017). Kása et al. (2018) pontosabb mintavételen alapuló becslése alapján a családi vállalkozások arányát a szakirodalomban közöltektől eltérően alacsonyabbra teszi, 57-66\% közé.

A magyar családi vállalkozás jellemzője, hogy a családtagok bevonása más motivációk alapján történik, mint a nyugati piacgazdaságokban. Ennek okai az adóterhek csökkentése, valamint az a lehetőség, hogy vállalkozói státuszban könnyebb munkát találni. A megélhetési színvonal emelése a fö motivációs tényező a vállalkozások alapításánál. A tervezettség, a tudatosság, a kiszámíthatóság alacsony mértékü az indulásnál (Soltész - Palotai, 2002 in: Salamonné, 2006).

A kutatásunk fő célkitűzése a családi vállalkozás jelenlegi utódlási nehézségeinek megragadása két nézőpontból, az utódlás szakaszos-folyamatos (Handler, 1989) és életciklus-alapú (Gersick et al., 1997) megközelítése alapján. A cikk felépítésében ezért első körben fontosnak tartjuk bemutatni e modelleket, valamint a hazai kutatások által már feltárt családi vállalkozások átadására, utódlására vonatkozó nehézségeket. 


\section{Utódlás a folyamatos és az életciklus-alapú modellek tükrében}

A kutatók egyetértenek abban, hogy az utódlás inkább egy folyamat, mint esemény (Churchill - Hatten, 1987; Friedman, 1986; Handler, 1990; Longenecker - Schoen, 1978). Nem egyszerüen egy lépés, ahol az egyik pillanatról a másikra átadják az irányítást vagy tulajdonlást, inkább több lépéses folyamatként kell kezelni, ami az idők során többször megtörténik, és azzal kezdődik, hogy az átvevő belép a szervezeti müködés egy funkciójába. Az utódlás folyamatát két különböző elméleti megközelítéssel lehet értelmezni:

egyrészt a szakaszos és folyamatos modellek (Longenecker - Schoen, 1978; Handler, 1989; Harvey - Evans, 1995; Stavrou - Swiercz, 1998; Keating - Little, 1997, Salamonné, 2006),

- másrészt az életciklus-alapú modellek (Greiner, 1998; Barnes - Hershon, 1976; Adizes, 1992; Danco, 1982; Quinn - Cameron, 1983; Churchill - Lewis, 1983; Churchill - Hatten, 1987; Ward, 1991; McGivern, 1989; Gersick et al., 1997) segítségével.

Míg a szakaszos-folyamatos modellek az átadást periodikusan ismétlődő folyamatként értelmezik, addig az életciklus-modellek a különböző tényezők mentén próbálják leírni az átadáshoz vezető szervezeti „életet”.

Handler (1989) modellje a kis szervezetek vezetésének átadására jól alkalmazható, hiszen az egyes szerepek elkülönítése a kis szervezetekben még jól tetten érhető, azzal jól leírható, illetve a vezetés átadási állapota is mérhető. $\mathrm{Az}$,utódlás táncának" nevezett modellben az átadás folyamatát olyan szakaszokra bonthatjuk, amelyek lehetnek speciálisan az utód érkezése előtti és utáni fázisok (Handler, 1989).) A harminckét családi vállalkozásnál végzett interjúja során azt tapasztalta, hogy ,,a következő generációs családtagok jelezték, hogy az ő szerepüket az elöd szerepe alakította" (Handler, 1990, p. 43.). Egy olyan kölcsönös szerepcsere-folyamatot írt le esettanulmányaiban, amelyben a szerepek nem különállóak, hanem az átadási folyamat során folyamatosan alakulnak, fejlödnek. Először nincs szerepe az átvevőnek, majd segítőként, menedzserként és végül vezetőként jelenik meg. Ezzel szemben az átadó, egyedüli irányító, majd uralkodó végül pedig átruházó és tanácsadó szerepeket vesz fel. A kölcsönös szerepcsere-folyamatot mutatja az 1. ábra.

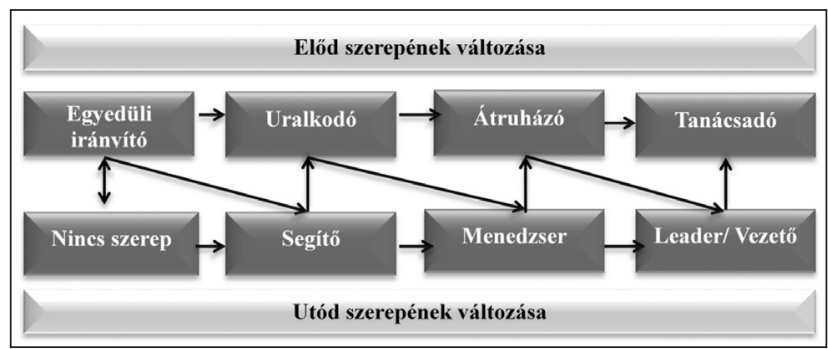

1. ábra Handler kölcsönös szerepcsere-kiegyenlítési folyamatának modellje

Forrás: Handler (1989, p. 194.)

A szerep kiegyenlítését úgy definiálhatjuk, mint a szervezetben a bevonás és a hatáskör csökkenő szintjét idö- ről-időre, személyes (egészség, kor és egyéb érdeklődés), szervezeti (növekedés, változtatás szükséglete, technológiai innováció) és környezeti (turbulencia, bizonytalanság) tényezőkre adott válasz (Pfeffer - Salancik, 2003). Handler (1990) kutatásai alapján négy átadó és négy átvevő szerepet különített el. Az első szakaszban az elöd, mint egyedüli irányító jelenik meg, amelynek során az alapvető alapítási és kezdeti vezetési feladatok ellátása a legfőbb tevékenysége. Ekkor a tulajdonos „maga a vállalkozás”. Az utód szerepe ekkor még nem jelenik meg, aminek az az oka, hogy még nem létezik, vagy nem ismerték fel annak fontosságát, hogy utódra lenne szükség, vagy a személyes, szervezeti vagy környezeti tényezők változásának nyomása még nem elég erőteljes. Handler (1989) szerint az utódlásban szerepet játszó generációk kora befolyásolja azt, hogy az utód mikor realizálja szerepét. Ekkor centralizált irányítás és paternalista kultúra jellemzi a vállalkozásokat. A következő szakaszban az elöd felveszi uralkodó szerepét, amely egy kimagasló hatalmat jelent a szervezet felett, legfőbb célja a szervezeti életképesség fenntartása. Az utód már, mint segítő lép be a szervezetbe. Limitáltan ugyan, de funkcionális feladatokat lát el, és elsajátítja a szervezet működését. Amikor az előd az átruházó szerepébe lép átadja a cégfelügyeletet és a saját felelősségét szervezet felett, kezd a vállalkozásból kivonulni, s az utód, mint menedzser a menedzseri feladatok átvételével belép a szervezetbe. Ez a legérzékenyebb pontja az átadási folyamatnak. Handler (1989) szerint sok vállalkozás el sem jut eddig a pontig, a szakaszon való átjutás függ a kölcsönös bizalomtól, a megosztás és delegáció képességétől. Sokszor egymás mellett kell, hogy együttmüködjön az átadó és átvevő hosszabb időn keresztül, míg az előd fel nem ismeri az átadás fontosságát. Az átadás utolsó szakaszában az előd már, mint tanácsadó jelenik meg, aki aktívan nem vesz részt a vállalkozás müködtetésében, jellemzően testületi tag. A kulcstényező a szakasz során a szervezettől való megválás nehézsége és annak kezelése, az utód leaderi szerepének kiépítése, s ezáltal a hatalom, befolyás és feladat teljes körű átadása. Az utódlás akkor fejeződik be, ha a vezetöi jogok mellett a tulajdonlás jogát is átadják a szervezetben (Handler, 1990).

A fenti, folyamatos modell alapján elmondhatjuk, hogy az ideális utódlási folyamat kezdő pontja az, amikor az utód még nem lép be a szervezetbe. A belépési szakasz föként a megismerésre és tanulásra helyezi a hangsúlyt. Majd, amikor az utód belép a formális hierarchiarendszerbe, menedzseri funkciókat vagy feladatokat vesz át, amely szakasz akkor ér véget, amikor az előd értékeli az utód munkáját, illetve pozitív kimenet esetén, átadja a teljes felelősséget, és az utód, mint teljes állású vezető kezd tevékenykedni. Az érett átadás abban áll, hogy az előd már kilép a szervezeti funkcióból, feladatból és az utód átveszi az irányítást (leaderi funkciót), s végül az utódlás ott fejeződik be, amikor az elöd a tulajdonlás jogát is átadja az utódnak. Továbbá Handler (1990) szerint, a sikeres utódlási folyamat a családi vállalkozásokban két tényezőtől függ: a folyamat résztvevőinek tapasztalatától (ami az interperszonális kapcsolatokon és az abban tapasztalt változásokon alapszik) és az utódlás hatékonyságától (hogyan itélik meg mások az átadás eredményét). 
A rendszer szempontú megközelítés, az életciklus-alapú modellek első kutatói az olyan akadályozó tényezőkre kívánták felhívni a figyelmet, mint a nepotizmus, a generációk közötti rivalizálás és a professzionalitástól mentes menedzsment a családi vállalkozásokban. A kutatások e korai szakaszában a családi vállalkozást, mint fogalmi kört két egymást részben átfedő rendszerként értelmezték: a család és az üzlet. Mindkét rendszer rendelkezik saját normáival, szabályaival, értékrendszerével és szervezeti struktúrájával. E megközelítés a mai napig általános érvényü a komplex szervezetiviselkedés-kutatás területein. Későbbiekben Davis és Tagiuri (1989) kutatásai felhívták a figyelmet arra, hogy az üzlet alrendszerét két különálló rendszerre kell bontani: a menedzsment és a tulajdonos rendszerére. Ennek legfőbb oka az volt, hogy míg vannak olyan szereplők a szervezetben, akik tulajdonosok azonban nincsenek bevonva a szervezeti működésbe, és vannak olyan egyének, akik a szervezet müködtetéséért felelösek, azonban nem rendelkeznek tulajdonhányaddal a szervezetben. Mindezek nyomán alakította ki Gersick et al. (1997) a családi vállalkozások háromkörös modelljét. E modell a családi vállalkozások rendszerét három független, de egymást átfedő alrendszerrel írja le: a család, az üzlet és a tulajdonlás.

Alapvetően e modell kialakítása megadta a keretet ahhoz, hogy egy lépéssel közelebb kerüljünk azon bonyolult rendszer megértéséhez, amely egy családi vállalkozásban alakulhat ki, legfőképpen személyes és szervezeten belüli konfliktusok, szerepdilemmák vagy éppen a családi vállalkozásban szerepet kapható egyének kijelölésében. Gersick et al. (1997) e rendszermodell időben megfigyelt fejlődésével és annak változásának leírásával alkotta meg a családi vállalkozások háromdimenziós fejlődési rendszer modelljét, mindezt úgy, hogy a háromkörös modell, minden köréhez három fejlődési dimenziót kapcsolt. Ahogy a 2. ábra mutatja az üzleti fejlődés az indulástól kezdve az érettség fázisáig halad, a család fejlődése ezzel párhuzamosan a fiatal üzleti fejlődéssel indul és a staféta átadásával fejeződik be, míg a tulajdonlás fejlődése szakasza a tulajdonos által kontrollált szakasztól indul és az unokatestvéri konzorciummal zárul.

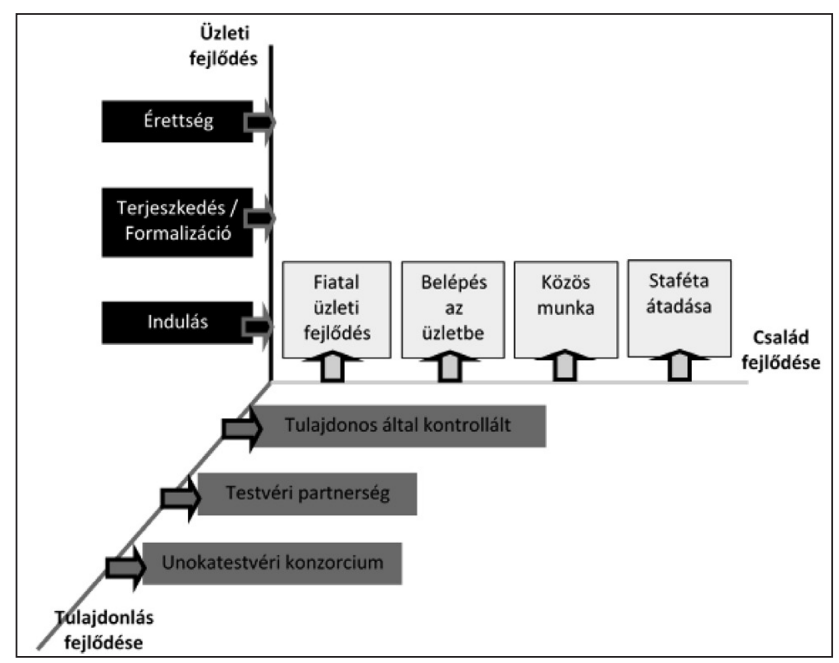

2. ábra A családi vállalkozások fejlődési modellje Forrás: Gersick et al. (1997, p. 10.)
Első körben a tulajdonlás egyszemélyes, ha van is másik tulajdonos ő nem vállal aktív szerepet a vállalat irányításában, míg a fejlődés utolsó szakaszában már a tágabb rokonság tulajdonolja a vállalkozást, és alkalmazott és nem-alkalmazott tulajdonosok is jelen vannak a struktúrában. A család fejlődése a fiatal üzleti fejlődésből indul ki, amelynek során jellemzően az idősebb generáció még 40 év alatt van, ha van is gyerek, ő még nagyon fiatal, ekkor a fó cél olyan vállalkozás létrehozása, ami alkalmas a munka világának menedzselésére, de a házasságéra is, valamint a gyerekek felnevelésére. A ciklus végén történik a stafétaátadás, ahol az idősebb generáció már 60 felett van, és a legföbb cél a cég elengedése, valamint nemcsak a vállalkozás, de a családi vezetés átadása is. Az üzleti fejlődés az indulás fázisával kezdődik, melynek során a vállalkozásra informális üzleti struktúra jellemző, tulajdonos-menedzserrel a középpontban. A ciklus végén pedig az érettség fázisa jelenik meg, ahol már a szervezeti struktúra a stabilitást támogatja, és fö cél a stratégiai re-fókusz (Gersick et al., 1997).

\section{A hazai családi vállalkozások utódlási nehézségei}

A vállalati életciklusmodellek segítséget nyújtanak a vállalkozások számára a növekedési problémák kezelésére. A családi vállalkozásokban hozzájárul ehhez az utódlás és generációváltás kérdése is. A vállalati és az emberi életciklusok összekapcsolásával vizsgálhatjuk a családi vállalkozások fázisait (Horváth, 2016). A növekedő hazai családi vállalkozások Salamonné (2006) modellje szerint a Kreativitás fázisában vannak. Ennek a ciklusnak a végén az irányítási krízis jelenik meg. A folyamatokat újra kell szervezni, új rendszereket kell bevezetni a pénzügyi és üzleti folyamatokra. Az ösztönzés területét is meg kell változtatni. Formalizálni kell a szervezetet, hatás- és felelösségi köröket kell meghatározni. Ennek a szakasznak a végén valójában a személyes vezetés válsága lép fel. Az intuitív, ad-hoc vezetésről át kell térni a professzionális vezetésre. Az alapítók, a jelenlegi vezetők közül az tudja sikeresen felvállalni ezt az új szerepet, akinek adottságai, képességei, tudása lehetővé teszi ezt. A másik lehetőség, hogy ezt a típusú vezetést külső szakemberre bízza a vállalkozás. Ebben az esetben nehézséget okoz, hogy a családi vállalkozások vezetői nehezen tudják rászánni magukat, hogy félreálljanak (Salamonné, 2006).

A családi vállalkozások közül még a stabil értékrenddel bíró vállalkozásoknak sincs megfelelő stratégiája, müködési folyamataik szabályozatlanok (Noszkay, 2017). Ez nemcsak a stratégiára, de Kása et al. (2017) szerint az utódlás stratégiájára is vonatkozik, hiszen az általuk felmért vállalkozók 41\%-a informális, nem írott utódlási stratégiával rendelkezik, míg 50\%-uk egyáltalán nem rendelkezik utódlási stratégiával. Hasonló feltételezésre jutott Noszkay (2017) is, ugyanakkor azt is kiemelte, hogy a hazai családi vállalkozásoknak nem feltétlenül van meg a sikeres utódláshoz a szakértelmük, vagy éppen nincs meg a megfelelő erőforrásuk (anyagi és ismeretbeli). A szakmai ismerethiány több szinten is problémát okozhat, hiszen a legtöbb tulajdonos-vezető szakmai tudással rendelkezik, 
de menedzsment és üzletfejlesztésivel nem (Mosolygó et al., 2018), vagy éppen a menedzsmentkultúra hiánya nehezíti az utódlási folyamatot (Noszkay, 2017).

A hazai családi vállalkozások szervezeti kultúráját és vezetői magatartását a tulajdonos-menedzser dominancia jellemzi. Ennek számos előnye és gyengesége azonosítható. A magyar családi vállalkozások mintegy $65-70 \%$-ban a házastárs, vagy más rokon is képviselteti magát a tulajdonosi és/vagy vezetői gárdában. Mindez azért jelent magas kockázatot, mert a személyes síkok az üzleti érdekkel ellentétesek lehetnek. Jellemző hiba, ha a kinevezések vezető elve a személyes kötődés és nem a kompetencia. A menedzsmentkompetenciák hiánya miatt viszont kevés családi vállalkozás éri meg a harmadik generációt, de akár még a másodikat is. Gyakori az elszigetelődés és az alacsony bizalmi szint (Konczosné, 2014). Kása et al. (2017) kutatása alapján elmondható, hogy a hazai családi vállalkozások több mint $80 \%$-a a családban szeretné továbbadni a tulajdonjogot, valamint a menedzsmentjogokat is.

A tudatosság és a megújulási, fejlődési irányultság, változtatási hajlandóság meghatározza a vállalkozás hoszszú távú sikerét (Vecsenyi, 2009). A hazai családi vállalkozások többsége olyan értékeket képvisel, mint a munkavállalókért való felelősségérzet, az előállított termék szeretete és a függetlenség, hosszú távú szemléletmód, a sokoldalúság és az életre szóló elkötelezettség, a tisztelet, maga a család (az összetartó erő), igazságosság, tisztesség és kitartás (Noszkay, 2017; Mosolygó et al., 2018). Ezért sem egyszerủ az utódlás kérdéséről beszélni, hiszen Noszkay (2017) szerint a legtöbb tulajdonos a cégügyeket sokszor "belügyként" kezeli, ami csak a családra tartozik.

A családi vállalkozások szervezeti rendszere egyszintü lineáris. Minden döntést a tulajdonos hoz meg. A hangya típusú vállalkozások általában a növekedés első fázisában vannak megrekedve. Amennyiben lendületet kapnak ezek a cégek - családi vállalkozás esetén, ha megtörténik az utódlás és az utód lendületes, lelkes -, a hirtelen dinamikus fejlődés gazellává teheti a vállalkozást (Csákné, 2012). Azonban gyakori, hogy a formalizált müködés megteremtése csak lassan és fokozatosan megy végbe a vállalkozásoknál. A vezetők nehezen engedik ki a hatalmat a kezükből, a funkcionális egységek vagy önálló üzleti területek vezetői csak fokozatosan kapják meg a tevékenységükhöz szükséges döntési jogokat (Salamonné, 2006). Egy felelős utódlási folyamat véghezvitele sokszor évekbe telik, azonban a hazai utódlással, átadással kapcsolatos információk hiánya nehézséget okozhat a folyamat véghezvitelében, ráadásul sokszor jellemző is, hogy a rendszerváltás idején alakult vállalkozások tulajdonosainak nincs meg az a menedzsmentismerete, ami az utódlás sikerességét adná (Noszkay, 2017; Mosolygó et al., 2018). Kása et al. (2018) kutatásaiból kiderült, hogy a hazai családi vállalkozók az alábbi kompetencia hiánnyal küzdenek: az innovációtól való tartózkodás, menedzsmentismeretek hiánya, munkaügyi szabályzatok, jogi ismeretek hiánya, pénzügyi ismeretek hiánya, idősebb korosztálynál az internetes elérhetőség problémája, a felszínes szakmai tudás, kevés tapasztalat (főleg az átvevő esetében), a tudatosság, kockázatvállalási hajlandóság hiánya, valamint a digitális kompetenciák hiánya.

A családi vállalkozások esetében az ún. Párhuzamos Tervezés Fontosságát fogalmazta meg Bogáth (2014.), mely a család és a vállalkozás összehangolt tervezését jelenti. Ezekben a vállalkozásokban magasabb a kockázat, hiszen nemcsak az anyagi javak, de a családi kapcsolatok is benne vannak a vállalkozásban, így a tervezés hiánya több konfliktushelyzettel és érzelmi hatással bír. Az utódlás tervezésével biztosíthatják a vállalkozás folytonosságát.

Makó et al. $(2016,2018)$ szerint azonban a fizikai tőke átadása sokkal kevésbé fontos a családi vállalkozások számára, mint az intangibilis tőke átadása, ezért is fontos a családi vállalkozások átadását több szinten megközelíteni (anyagi, érzelmi és családdinamikai) (Noszkay, 2017). Hiszen a vállalkozások fennmaradása azok hoszszú távú sikerén és a családi összetartáson is múlik. Az átadás típusa alapján el lehet különíteni a magyarországi vállalkozásokat a rendszerváltás idején alapítottakra, akik a tulajdont és a vezetői funkciójukat átadták, de a vezetői szerepüktől nehezen válnak meg. A másik csoportot a válságot megelőzően alapították, akik sem a tulajdont, sem a vezetést nem adták át. A kisvállalkozások nem engedhetnek meg magunknak egy professzionális menedzsert, ugyanakkor belső utódokat sem nevelnek ki. Az utódlás tervezésének fontossága ebben is megnyilvánul, hiszen nem lehet egyik pillanatról a másikra átadni azt a morált, vállalati kultúrát, tudást, amit a tulajdonosvezető hosszú évek alatt beépített a szervezetbe (Bogdány - Csizmadia, 2017).

Az utódlás sikertelensége a tervezetlenségben és felkészületlenségben keresendő (Csákné, 2012). A magyar vállalkozók többségének nincs tapasztalata az utódlásban. Az elképzelés szintjén marad meg a visszavonulás terve, kevesen jutnak el a cselekvésig és még ritkább a tudatos stratégia és kommunikáció. Nehézséget okoz a család és a vállalkozás érdekeinek szétválasztása. Szimbolikus és valós kulcsszerepüket nagyon nehezen adják fel. Üzletmérettől függően más és más vezetői stílus lenne szükséges, ugyanakkor általában a családi vállalkozás egy növekedési szintet elérve gyakran nem képes üzemszerü és strukturált müködésre átállni (Csákné, 2012). Annak érdekében, hogy a vállalkozásokban a fejlődési folyamat generációkon keresztül jól müködjön, fontos, hogy a hazai kis- és közepes vállalkozások az átadással járó feladatokat tervszerűen és felkészülten végezzék el (Karmazin - Gál, 2016).

Gyakran előforduló utódlással kapcsolatos probléma az is, hogy az utód nem akarja, nem képes átvenni a vállalkozást (Kása et al., 2017; Noszkay, 2017; Mosolygó et al., 2018), vagy nincs utód, aki átvenné, vagy a tulajdonos háttérbevonulása csak jelképes (bizalomhiány az utódban, tétlenség érzete) (Kása et al., 2017), esetleg az utód csak a “választás illúzióját" kapja meg és bizonyos pszichológiai nyomás hatására veszi át a vállalatot (Mosolygó et al., 2018).

A fent bemutatottak alapján összefoglalhatók (1. táblázat) a legfontosabb utódlási nehézségek, problémák, amelyek a hazai családi vállalkozásokat érintik. 


\begin{tabular}{|l|l|}
\hline $\begin{array}{l}\text { Szabályozatlanság és } \\
\text { informális utódlási } \\
\text { stratégia }\end{array}$ & $\begin{array}{l}\text { Kása et al. (2017); } \\
\text { Noszkay (2017); } \\
\text { Csizmadia et al. (2016) }\end{array}$ \\
\hline $\begin{array}{l}\text { Elsó számú tulajdonos- } \\
\text { vezetői információs- } \\
\text { dominancia }\end{array}$ & Kása et al. (2017) \\
\hline $\begin{array}{l}\text { Szocio-emocionális tőke } \\
\text { megőrzése }\end{array}$ & $\begin{array}{l}\text { Makó et al. (2016), (2018); } \\
\text { Mosolygó et al. (2018); } \\
\text { Csizmadia et al. (2016) }\end{array}$ \\
\hline $\begin{array}{l}\text { Az utód hiánya, } \\
\text { más tervei }\end{array}$ & $\begin{array}{l}\text { Kása et al. (2017); } \\
\text { Noszkay (2017), } \\
\text { Mosolygó et al. (2018) }\end{array}$ \\
\hline $\begin{array}{l}\text { Üzleti és menedzsmentis- } \\
\text { meret hiánya és } \\
\text { átadásának hiánya }\end{array}$ & $\begin{array}{l}\text { Mosolygó et al. (2018); } \\
\text { Noszkay (2017) }\end{array}$ \\
\hline $\begin{array}{l}\text { Utód bevonásával } \\
\text { kapcsolatos problémák }\end{array}$ & $\begin{array}{l}\text { Kása et al. (2017); } \\
\text { Mosolygó et al. (2018); } \\
\text { Noszkay (2017); } \\
\text { Csizmadia et al. (2016) }\end{array}$ \\
\hline $\begin{array}{l}\text { Tulajdonos-vezetó és } \\
\text { nem családi tagok } \\
\text { közötti konfliktusok }\end{array}$ & Csizmadia et al. (2016) \\
\hline $\begin{array}{l}\text { Erőforráshiány } \\
\text { az utódláshoz }\end{array}$ & Noszkay (2017) \\
\hline
\end{tabular}

1. táblázat A hazai családi vállalkozások utódlással kapcsolatos nehézségei

A bemutatott szakirodalmi összefoglaló alapján fő célként tűztük ki, hogy megvizsgáljuk az adott vállalkozási körben, mennyiben azonosíthatók a bemutatott folyamatos és életciklusmodell különbözö fázisai, azok milyen jellemzőkkel írhatók le, valamint milyen nehézségek jelennek meg az egyes szakaszok során.

\section{A kutatás módszertana}

A kutatás során az adatgyüjtésre kvalitatív módszereket alkalmaztunk. A kvalitatív kutatások megkülönböztetését a kvantitatív kutatásoktól az indokolja, hogy a valós világban megfigyelhető tények jelentős része nem mennyiségi, számokban kifejeződő formában jelentkezik, illetve nem szükségszerü a kutatáshoz tartozó minden tényt számokban kifejezni. A kvalitatív módszer a legjobb módszer akkor, ha a „hogyan” és „miért” kérdésekre keressük a választ (Yin, 2009).

Az empirikus kutatás céljából készített interjúk sajátossága a személyhez való nagyfokú alkalmazkodás lehetősége. Ez a módszer kötetlenebb, mint a kérdőív, lehetővé teszi mind a vizsgált, mind a vizsgálatunk szempontjából marginális jelentőségü témákban való elmélyülést. További előnye a módszernek, hogy interperszonális volta miatt mód van az azonnali reagálásokra, visszacsatolásokra (Yin, 2009). Mivel kutatásunk során a mögöttes motivációk, nehézségek feltárására tettünk kísérletet, ezért az interjú módszertana a kívánt módszer.

A vizsgálatba bevont vállalatok vezetőivel (az átadókkal), valamint néhány esetben a leendő utóddal interjút készítettünk, hogy megismerjük a vállalat történetét, jelenlegi helyzetét és az utódlással kapcsolatos terveit. A vállalatoknál készített interjúkból származó információkat esettanulmányok formájában dolgoztuk fel. Véleményünk szerint az esettanulmány megfelelöen alkalmazható a valós világ gyakorlatának leképzésére. „Az esettanulmány módszer lehetőséget ad a valós világ holisztikus és jelentőségteljes jellemzőinek megőrzésére - úgy, mint az egyéni életciklusok, szervezeti és menedzseri folyamatok...és az iparágak (és szervezetek) érettsége" (Yin, 2009, p. 9.). Az esettanulmány meg kell, hogy feleljen bizonyos követelményeknek: szavahihetőség, hitelesség, megerősíthetőség, adatmegbízhatóság. Ezekhez az alábbi tesztek szükségesek: szerkezeti, belső, külső validitás és megbízhatóság, amelyekhez különböző technikákat lehet alkalmazni (Yin, 2009). Kutatásunkat az esettanulmány-protokoll segítette, amely alapján azonos körülmények között az eredmények megismételhetővé válnak, ez nem jelenti ugyan az eredmények általánosíthatóságát, csupán azt, hogy az esettanulmány-protokollt követve ugyanezen eredményekre juthatunk.

A 2. táblázatban összefoglaltuk a kutatás során használt adatgyüjtési és elemzési módszereket, valamint a kutatási kérdéseket.

\begin{tabular}{|c|c|c|}
\hline $\begin{array}{l}\text { Kutatási } \\
\text { kérdések }\end{array}$ & Adatgyüjtés & $\begin{array}{l}\text { Elemzési } \\
\text { módszer }\end{array}$ \\
\hline $\begin{array}{l}\text { A vizsgált családi } \\
\text { vállalkozások Handler } \\
\text { és Gersick et al. mo- } \\
\text { dellje alapján az utódlás } \\
\text { mely fázisában vannak? }\end{array}$ & \multirow{3}{*}{$\begin{array}{l}\text { Félig } \\
\text { strukturált } \\
\text { interjú }\end{array}$} & \multirow{3}{*}{ Esettanulmány } \\
\hline $\begin{array}{l}\text { A vizsgált családi } \\
\text { vállalkozások jelenlegi } \\
\text { utódlási állapota Hand- } \\
\text { ler és Gersick et al. } \\
\text { modellje alapján hogyan } \\
\text { jellemezhető? }\end{array}$ & & \\
\hline $\begin{array}{l}\text { A vizsgált családi } \\
\text { vállalkozások milyen } \\
\text { nehézségekkel, } \\
\text { kihívásokkal } \\
\text { szembesülnek az egyes } \\
\text { fázisok során? }\end{array}$ & & \\
\hline
\end{tabular}

\section{2. táblázat A kutatás struktúrája}

A kutatásba bevont vállalkozások kiválasztásánál az alábbi szempontokat vettük figyelembe:

- hosszú távon, nyereségesen müködő (több mint tíz év) vállalkozás,

- a vállalkozási méretét tekintve a KKV-szektor köréből mikro- és kisvállalkozások,

- családi tulajdonú vállalkozás, ami családi vállalkozásként definiálja magát,

- a vállalkozás az utódlás kérdésében érintett legyen,

- az átadás terve a családon belül, generációváltás keretében történjen.

Hasonló szempontok szerint történő mintaválasztást találhatunk Mosolygó et al. (2018), Bogdány (2014) kutatásában is.

Az interjúkat 2018. januárban és februárban folytattuk le, a beszélgetések egy elöre összeállított interjúvázlat alapján, kb. 1,5 óra időtartamban zajlottak a vállalkozások 
székhelyén. Az interjú, mint négyszemközti beszélgetés lehetőséget teremtett, hogy megbízható információkhoz jussunk. A minta elemszáma ugyan nem elegendő ahhoz, hogy általános képet fessünk a magyar kis- és középvállalkozások müködéséröl, szervezeti rendszeréröl és az utódlási terveikről, ahhoz viszont elegendő, hogy jó gyakorlatokat, megfontolandó kérdéseket feltárjunk ebben a témában. Az adatok összegyüjtése megismételhető, azaz a vállalkozások vezetői ezekkel az információkkal szolgálnának az interjú ismételt lefolytatása során is az interjúprotokollból adódóan. Az interjúk összefoglalását megosztottuk az alanyokkal, amit ők jóvá is hagytak. Az interjúk során az alábbi témákat tárgyaltuk át minden interjúalannyal:

- az interjúalany jellemzői, alapadatok,

- a családi vállalkozásról alkotott általános kép,

- a vállalkozás története, alapvető jellemzői,

- a müködés jogi formái, tulajdonosi szerkezete, szervezeti-vezetési felépítése és az ezekben történt változások, formális és informális rendszerek változásai, a formális pozíciók kialakulása, sorrendje, müködési konfliktusok, nehézségek, a családi vállalkozás müködésére jellemző specifikus elönyök, nehézségek,
- a vállalkozás mérföldkövei, a vállalkozás életciklusai - a növekedés stációi - jelenlegi helyzete, a növekedésből adódó konfliktusok,

- átadási tervek, folyamatok, célok

- formális/informális utódlási terv/stratégia,

- gyerekek szerepvállalásai, betöltött pozíciói a vállalkozásban,

- utódokkal szembeni elvárások, utódok alkalmassági szempontjai,

- utódok oldala

- „családi vállalkozásban felnőni”: a vállalkozás pozitív és negatív hatásai a családban,

- a potenciális utóddá válásnak milyen hatásai voltak (tanulmányok, karriercélok), az utódlás motivációja,

- az utód szerepvállalási folyamata a vállalkozásban,

- a generációs különbségekből adódó nehézségek és ezek kezelése, kommunikáció előd és utód között, az utód tervei, célkitűzése,

- jövőbeli tervek, célok.

A kutatásban részt vevő vállalkozásokat mutatja be a 3. táblázat.

\begin{tabular}{|c|c|c|c|c|c|}
\hline \multicolumn{6}{|c|}{ Vállalkozások adatainak összefoglaló táblázata } \\
\hline Vállalkozások & I. & II. & III. & IV. & $\mathrm{V}$. \\
\hline Társasági forma & $\mathrm{Kft}$ & $\mathrm{Kft}$ & Kft & egyéni vállalkozás & $\mathrm{Bt} / \mathrm{Kft}$ \\
\hline Alapítás éve & 1991. & 1992. & 1993. & na. & 1998./2003. \\
\hline Típusa & kisvállalkozás & kisvállalkozás & mikrovállalkozás & egyéni vállalkozás & mikrovállalkozás \\
\hline Tevékenységi köre & $\begin{array}{l}\text { reklám-ajándék } \\
\text { kereskedelem }\end{array}$ & $\begin{array}{l}\text { csomagolóanyag- } \\
\text { gyártás, } \\
\text { kereskedelem }\end{array}$ & $\begin{array}{l}\text { nemzetközi } \\
\text { árufuvarozás }\end{array}$ & $\begin{array}{l}\text { mezőgazdaság, } \\
\text { növénytermesztés }\end{array}$ & $\begin{array}{l}\text { reklám-ajándék } \\
\text { kereskedelem, } \\
\text { emblémázás }\end{array}$ \\
\hline Árbevétele MFt (2016.) & 2493 & 2842 & 292 & na. & 138 \\
\hline Létszáma (fö) & 51 & 86 & 12 & 1 & 8 \\
\hline Tulajdonosi viszony & 2 utód, 5 igazgató & alapító házaspár & alapító & utód & alapító házaspár \\
\hline
\end{tabular}

3. táblázat A kutatásban részt vevő vállalkozások összefoglaló táblázata

\begin{tabular}{|c|c|c|c|c|c|}
\hline $\begin{array}{c}\text { Vállalkozás/ } \\
\text { Strukturális } \\
\text { jellemző }\end{array}$ & I. & II. & III. & IV. & V. \\
\hline Munkamegosztás & $\begin{array}{l}\text { funkcionális elvű, } \\
\text { egydimenziós }\end{array}$ & $\begin{array}{c}\text { funkcionális elvü, } \\
\text { egydimenziós }\end{array}$ & $\begin{array}{l}\text { funkcionális elvü/ } \\
\text { rugalmas, } \\
\text { egydimenziós }\end{array}$ & funkcionális & $\begin{array}{l}\text { funkcionális elvü/ } \\
\text { rugalmas } \\
\text { egydimenziós }\end{array}$ \\
\hline $\begin{array}{c}\text { Hatáskör-meg- } \\
\text { osztás }\end{array}$ & $\begin{array}{l}\text { centralizált, } \\
\text { egyvonalas }\end{array}$ & $\begin{array}{l}\text { centralizált, } \\
\text { egyvonalas }\end{array}$ & $\begin{array}{l}\text { centralizált, } \\
\text { egyvonalas }\end{array}$ & centralizált & $\begin{array}{c}\text { centralizált, } \\
\text { egyvonalas }\end{array}$ \\
\hline Koordináció & $\begin{array}{l}\text { strukturális, } \\
\text { személyorientált, } \\
\text { lapos hierarchia }\end{array}$ & $\begin{array}{l}\text { strukturális, } \\
\text { technokratikus, } \\
\text { személyorientált, } \\
\text { lapos hierarchia }\end{array}$ & $\begin{array}{l}\text { személyorientált, } \\
\text { lapos széles } \\
\text { hierarchia }\end{array}$ & személyorientált & $\begin{array}{l}\text { személyorientált, } \\
\text { lapos széles } \\
\text { hierarchia }\end{array}$ \\
\hline Konfiguráció & $\begin{array}{l}\text { háromszintü } \\
\text { mélységi tagolás }\end{array}$ & $\begin{array}{c}\text { háromszintü } \\
\text { mélységi tagolás }\end{array}$ & $\begin{array}{c}\text { kétszintü } \\
\text { mélységi tagolás }\end{array}$ & $\begin{array}{c}\text { egyszintü } \\
\text { mélységi tagolás }\end{array}$ & $\begin{array}{c}\text { kétszintü } \\
\text { mélységi tagolás }\end{array}$ \\
\hline Egyéb jellemzők & $\begin{array}{c}\text { részben } \\
\text { szabályozott/ } \\
\text { standardizált, } \\
\text { gyengén } \\
\text { formalizált }\end{array}$ & $\begin{array}{c}\text { részben } \\
\text { szabályozott, } \\
\text { standardizált, } \\
\text { közepesen } \\
\text { formalizált }\end{array}$ & $\begin{array}{l}\text { szabályozatlan, } \\
\text { részben } \\
\text { standardizált, } \\
\text { gyengén } \\
\text { formalizált }\end{array}$ & $\begin{array}{l}\text { szabályozatlan, } \\
\text { standardizált, } \\
\text { gyengén } \\
\text { formalizált }\end{array}$ & $\begin{array}{l}\text { szabályozatlan, } \\
\text { részben } \\
\text { standardizált, } \\
\text { gyengén } \\
\text { formalizált, }\end{array}$ \\
\hline
\end{tabular}

4. táblázat A vizsgált vállalkozások strukturális jellemzői 


\section{Az esettanulmány eredményeinek bemutatása}

Az eredmények ismertetésének íve a kutatási kérdések logikáját követi. Így első körben az utódlási fázisok beazonosítása és jellemzése történt meg, majd a feltárt nehézségek bemutatása következik.

\section{Üzleti fejlődési ág (Gersick et al. 1997)}

A vállalkozások strukturális jellemzői a 4. táblázatban láthatók.

A 4. táblázatban látható, hogy a vizsgált vállalkozások egyszerüen strukturáltak. A munkamegosztásra a funkcionális felosztás jellemző, sok szabályozatlan, a feladatokhoz egyedileg alkalmazkodó munkakörrel. A funkcionális elv a kisvállalkozásokban egyértelmübb. A hatáskör centralizált, a vezető kezében vannak a döntési jogkörök. A kisvállalkozásoknál már árnyaltabb a kép: a középvezetői szint már rendelkezik korlátozott döntési hatáskörrel. A vállalkozások lapos hierarchiarendszerrel rendelkeznek. A koordinációs eszközök közül a személyorientált a jellemző mindegyik vállalatnál. A mikrovállalkozások munkafolyamatainak csak egy része standardizált, tehát szabályozott, de ezek a szabályok is többnyire informálisan meghatározottak. A II. számú termelő vállalkozásnál a standardizáltság/szabályozottság foka erősebb és ezeknek a szabályoknak a közlési módja is már több esetben formális.

A strukturális jellemzőkböl fakadó előnyök a vizsgált vállalkozásoknál:

- rugalmasság, gyors döntéshozatal,

- egyértelmű alá- és fölérendeltség,

- a közvetlen utasítások miatt nincs információveszteség.

Tapasztalataink alapján amennyiben a szabályozottság foka erősebbé válik, és ezek közlésének módja írásban rögzítésre kerül - formalizálttá válik -, az utód számára könynyebbé válik a vállalkozások vezetésének átvétele.

A vállalkozások növekedésével kapcsolatban a vezetők a jelenlegi méretet tartják kívánatosnak. Összetettebb struktúrákban nem gondolkodnak, a meglévő szervezeti rendszert átlátják és működőképesnek tartják. A tulajdonosok érzékelik a határaikat, melyekkel még felelősen tudják vezetni a vállalkozást. A formális tervezést/szabályozottságot a vezetők nem tartják indokoltnak ekkora cégméret esetén. Jövőbeni céljaik között a folyamatos technológiai megújulás, a hatékonyabb eredményesebb müködés fejlesztése szerepel. A hatékonyabb működés megvalósításában eszköz a szabályozó rendszer bevezetése, de ezek az újítások nem kapcsolódnak közvetlenül az utódlás folyamatához. Az I. számú vállalkozás vezetője szerint „a fejlesztésnek csak közvetve van pozitív hatása a vállalkozás közeljövőben megvalósuló átadására."

A vezetők ezeken a struktúrákon jellemzően nem akarnak változtatni, a müködési kereteket a meglévő szinten szeretnék tartani. Szeretnék megörizni a vállalkozások családias jellegét. „Fontos a családias hangulat, a közvetlen légkör a cégben”. „Nem vágyunk többre, a családiasság, a tisztességes megélhetés a legfontosabb" - vélekedtek a cégvezetők. A folyamatok, szabályok, írásban való rögzítését feleslegesnek tartják. Az utódlás folyamata nincs hatással a szervezetek strukturális jellemzőinek megváltoztatására és a formalizáltságának mértékére. A formalizáltság mértéke a vállalkozásokban a szervezet méretének növekedésével és működési rendszerének összetettebbé válásával erősödik. A formalizáltságot közvetlenül meghatározza, a standardizáltság és a szabályozottság foka, változásuk egyenes arányos.

Családi fejlődés (Gersick et al., 1997)

\begin{tabular}{|c|c|c|c|c|c|}
\hline Vállalkozás & I. & II. & III. & IV. & V. \\
\hline Alapító életkora & 50 év & 63 év & 62 év & 67 év & 46 év \\
\hline Utód életkora & 25 év & 33 év & n.a. & 33 év & 21 év \\
\hline
\end{tabular}

5. táblázat $A$ vizsgált vállalkozók életkora

Az 5. táblázat alapján beazonosítható, hogy az I., II. és III. vállalkozás a közös munka fázisában van. A vállalkozások formális utódlási tervvel nem rendelkeznek, azonban elképzeléseik vannak az átadás folyamatáról. A vállalkozások átadói minden esetben gyermekeiknek készülnek átadni a vállalkozás irányítását, fontosnak tartják az utódok felkészültségét ebben a tekintetben, például iskola elvégzése, belső motiváció megmutatkozása. Az I. számú vállalkozásnál az utódok iskolai végzettsége illeszkedik a vállalkozás tevékenységéhez. Ezt így fogalmazta meg az alapító: „ha olyat tanultok, ami a vállalkozásnak hasznos, akkor jöhettek”. Az alapító meglátása az, hogy a gyerekek többet tudnak tanulni a cégben a vezetési struktúra és a cégméret miatt, mint máshol. Egy független vállalatnál is sok tapasztalatot, tudást tudnak gyüjteni, de ott valószínüleg csak egy területet kapnak (ahol van lehetőség professzionális tudásra szert tenni), de a vállalat teljes egészére, egyéb funkcionális egységeire nem, vagy korlátozottan látnak rá.

Jellemző, hogy az utód, belépése előtt már belelát a vállalkozás tevékenységébe, ismerkedik annak bizonyos feladataival. Az I. számú vállalkozásnál az átadást megkönnyíti, hogy nem közvetlenül az alapítók alá/mellé tartoznak az utódok a szervezeti struktúrában, így a szorosabb - családi - kapcsolatból adódó viták, konfliktusok elkerülhetők. Tisztább, munkatársi viszony van így a felek között. Objektíven tudnak tanulni, tapasztalatokat szerezni a kollégáktól úgy, hogy közben sok segítséget, figyelmet és útmutatást kapnak. A tulajdonosi helyzet miatt több teher is van rajtuk, aminek meg kell felelniük. A vállalkozások fő célja, olyan környezet megteremtése, ami alkalmas lehet az utódlás teljes körü lebonyolítására, azonban ezek a feltételek inkább tervezetlenül, ad-hoc jelleggel mennek végbe, az üzleti fejlődés adta lehetőségekből adódóan. A II. számú vállalkozásnak sincs formalizált utódlási terve. Az alapító még tíz évig szeretné a vállalkozást vezetni, erős ambíciói vannak még a vezetésre. $\mathrm{Az}$ átadásra részletes koncepciót nem alakított ki, az utód munkájával elégedett, de úgy gondolja a vezetésre még nem alkalmas. Az utód edukációjának szükségességét megfogalmazta, de konkrét elképzelése erről a folyamatról nincs.

A III. számú vállalkozásnál már elindult vezetői szerepek átadása. Jelenleg az alapító és az utód közösen vezeti a vállalkozást. Az alapító tervei szerint a következő években szeretné a vezetés felelősségét teljes mértékben átadni, majd azt követően a tulajdont is. Időtervet nem határozott meg az alapító. Az átadás eddigi folyamata illeszkedett az utód életkorához. Iskolái befejezésekor csatlakozott munkavállalóként a vállalkozáshoz és fokozatosan lépett a vezetői szerepbe.

A IV. számú vállalkozást már teljes mértékben átadták, jelenleg a staféta átadási fázisban van. Az utódlás folyamata 
itt is az alapító egyik gyermekének ambíciójával indult, ami az alapító elképzelésével összhangban volt. A tanulmányok és a vállalkozás tevékenységében való folyamatos részvétel alapozta meg az átvételt. Az átadást elősegítette egy minisztériumi rendeletben meghatározott pályázatban való részvétel ${ }^{1}$. A pályázat arra ösztönözte az alapítót, hogy a teljes gazdaságot átadja az utódnak (adó- és illetékkedvezmények, járadék juttatása az átadónak). A pályázat beadásakor az utódnak már több éves munkatapasztalata volt, így viszonylag egyszerüen, gördülékenyen megvalósult az átadás.

Az V. számú vállalkozás utódlási tervezése szintén az utód átvételi ambícióinak megnyilvánulásakor kezdődött, jelenleg a vállalkozás a modell szerinti ,üzletbe való belépés" fázisában van. Az alapító ezt megelőzően a vállalkozás eladását határozta meg jövőbeli célként. Amikor az alapító egyik gyermekében felmerült az átvétel terve, és a szándék komolyságát bizonyította a vállalkozásban alkalomszerűen végzett munka iránti elhivatottságával, akkor kezdte el az alapító tervezni a vállalkozás átadását.

A vizsgált vállalkozások utódlási tervvel rendelkeznek, de a terv sehol nem került írásban rögzítésre. Ennek oka, hogy a vállalkozások müködése gyengén formalizált. A tervezés jellemző a vállalkozásokra, de ennek írásbeli rögzítése nem. Esetükben az utódlási terv, a vállalkozás vezetői szerepének és tulajdonjogának átadására vonatkozó terv, amely informálisan van meghatározva, időszakokra lebontva.

Példaként az I. számú vállalkozás utódlási terve:

- 3 év időtartam (2017-2019) - az alapító az ügyvezetö, az utódok az operatív munkában vesznek részt.

- 3 év időtartam (2020-2022) - hárman lesznek ügyvezetök, a területek ( $k b$. 20 felelösségi terület - 5 igazgató alatt) fel lesznek osztva az utódok között. A struktúrában az igazgatók fölé kerülnek az utódok és a cégvezető mellé. Közös együttmüködés a vezetésben. Vitás kérdésekben a többség dönt. Tulajdonosi szempontból nézve a két utódnak már megvan a lehetösége az alapitó ügyvezetö leváltására. Az alapitó szerint ez azért fontos, mert sok cégátadás ezen a ponton hiúsul meg. Az alapító nem akar kivonulni, az utódok pedig nem tudják kirakni-ezáltal tönkreteszik a céget, mert annyira fog mindent az alapitó, hogy az utód nem tudja átvenni. Be kell látni az alapítónak, hogy ez már a következö generáció élete, felelössége, kockázata. Fontos megemliteni, hogy esetükben megvan az anyagi biztonsága az alapitónak - igy könnyebb ennek a döntésnek is alávetnie magát és belátni a korlátait.

- 3 év időtartam (2023-2025) - két utód az ügyvezetö - kettös vezetés (ezt kell kialakitani ebben a három évben) felosztott feladat- és felelösségkörökkel. Az alapító tanácsadói szerepben.

Az utódlási terv nem mereven meghatározott, egy keretet ad az átadási folyamatnak. A hároméves periódusok beláthatók, tervezhetők. Mindegyik szakasz egy folyamatot ölel fel, és a periódusok között átfedések is vannak. Ha a helyzet megkívánja, bármikor/bármennyiszer felülírható a terv.

Mindegyik cég érintett az utódlás kérdéskörében, az átadó és az utód életkora és élethelyzete adja, hogy a vállalkozások megtervezik-e ezt a folyamatot. Minden esetben, amikor megtalálták a vállalkozások a potenciális utódot, akkor tervezték meg az utódlás folyamatát. Az informális utódlási tervekben azonban az utóddal szemben nem fogalmaztak meg elvárásokat.

Az egyik vezető így fogalmazott: „Alulról kell kezdeni, minden tevékenységet végeznie kell az utódnak". A munka végzésének minősége is elvárás „ami a legjobban tetszett az a hozzáállás", mondta az V. számú cég vezetője az utódról. Nagyon fontosnak tartják a bizalmat, az együttműködés képességét, ami lehetővé teszi az utód tanítását. Az utód tanulmányai irányában szempont volt a vállalkozásban való hasznosítás lehetôsége, azonban az utódok szabad döntéssel rendelkeztek minden esetben.

\section{A tulajdonlás fejlődése (Gersick et al., 1997)}

\begin{tabular}{|l|c|c|c|c|c|}
\hline Vállalkozás & I. & II. & III. & IV. & V. \\
\hline Tulajdonátadás & igen & nem & nem & igen & nem \\
\hline
\end{tabular}

\section{6. táblázat A tulajdonlás változása}

A 6. táblázatban látható, hogy az I. és a IV. vállalkozásnál a tulajdonátadás megtörtént, azonban az I. vállalkozás speciális helyzetben van, hiszen ott a vezetés átadása még nem történt meg ezzel egyidejüleg. Az I. számú vállalkozásnál a tulajdonátadás - az általánosan elfogadott sorrendhez képest fordított módon - már megtörtént. Ennek oka, hogy az alapító a vállalkozás tulajdonában lévő ingatlanvagyont, valamint a tevékenységet a hozzá kapcsolódó eszközökkel együtt szét kívánta választani. Ennek gazdasági okai voltak. Így a tulajdon átadása megelőzte a vezetői funkciók átadását. Az ingatlan maradt az átadóé (egy másik gazdasági társaságban), az utódoké pedig a tevékenység (I. számú vállalkozás). A két utód tulajdoni részesedése 42,5-42,5\%, valamint tulajdonrészt kapott a jelenlegi öt igazgató is (3$3 \%$ ). Az alapítónak a tevékenységet átvevő cégben nincs tulajdonjoga, alkalmazottként cégvezető. Igazgatóknak adott tulajdonrész legfőképpen elismerés, valamint egy motiváció is a további hatékony munkához az azonos érdekeltség biztosításával. Az alapító utódlási döntését, az átadás körülményeit meghatározza, hogy az ő tulajdonában maradt ingatlan biztos megélhetést biztosít számára a jövőben. Ebből kifolyólag „könnyen” tudta a tulajdont átadni, mert nincs már a tevékenységből megélhetési érdeke. Ha csak a tevékenység van, akkor valószínüleg nem lett volna ilyen könnyü ez a kérdés. A IV. számú vállalkozásban már megtörtént a teljes átadás. A tulajdon teljes mértékben átkerült az utód kezébe. Az alapító másik gyermeke hozzájárult a teljes vállalkozási vagyon átruházásához a testvére tulajdonába, ő más területen dolgozik, és nem kíván részt venni a vállalkozásban.

\footnotetext{
Az Európai Mezőgazdasági Vidékfejlesztési Alapból a mezőgazdasági termelők gazdaságátadásához a 2012. évtől igényelhető támogatások részletes feltételeiről szóló 121/2012. (XI. 28.) VM rendelet módosítása.
} 
A másik három vállalkozás esetében a tulajdon még az átadó kezében összpontosul, melynek több oka is felmerült: nem határozták meg a tulajdon felosztás tervét; az alapító mindenképpen meg akar tartani magának tulajdoni hányadot, mert az állami nyugdíj nem fedezi a megélhetését, a vezetés és a tulajdon átadás egyidejüleg fog lezajlani.

\section{A vállalkozások utódlási folyamatának jellemzése Handler (1989) modellje szerint}

A vállalkozások az előzőekben bemutatott struktúrák szerint, nyereségesen és hosszú távon müködnek. Mindegyik vállalkozás elérkezett az indulási és növekedési életciklust követően abba a fázisba, amikor érintett az utódlás kérdésében. Az alapító vállalkozók életkora közeledik, vagy már el is érte a nyugdíjkorhatárt, így a vállalkozások továbbvitele megoldandó probléma.

A vállalkozások az utódlás különböző fázisaiban vannak. Az I. számú vállalkozásnál már megtörtént a tulajdonátadás, mindkét utód már a vállalkozásban dolgozik. A II. és III. vállalkozás esetében még sem a tulajdont, sem a vezetői szerepeket nem adták át teljesen, az utód munkavállalóként dolgozik a cégben. A IV. számú vállalkozásnál már megtörtént a teljes átadás. Az V. számú vállalkozás van az utódlás leginkább kezdeti fázisban: az utód még tanul, csak alkalmi munkákat végez a vállalkozásban.

A IV. számú vállalkozásnál már végbement az átadás folyamata. Az utód ugyanabban a struktúrában müködteti a vállalkozást, mint az édesapja. A II. és III. számú vállalkozásnál már fóállásban dolgoznak a potenciális utódok. Ahol megindult a vezetés átadásának folyamata, ott a vezető mellett dolgozik, ahol még nem indult el a folyamat, ott a meglévő struktúrába illesztették be az utódot konkrét feladatkörrel.

Az utódlás lehetséges lépései azonosíthatók a vállalkozásoknál és összekapcsolhatók a handleri szerepcseremodell szakaszaival. Mindegyik vállalkozás egy folyamatként tekint az átadásra, amiben a vezető szerepe fokozatosan kerül át az alapítótól az utódhoz.

A vezetői szerepek átadása a családi vállalkozásokban olyan folyamaton megy keresztül, amelynek során a felelősség és az irányítás fokozatosan kerül át az átadótól az utódhoz. A vezetői szerepek átadási modelljének és az utódlás lépéseinek összekapcsolása során látható, hogy a szerepcsere magába foglal több utódlási lépést. A következőkben a handleri modell szerint a vállalkozásoknál megjelenő szerepcsere-folyamatot mutatjuk be, részletesen jellemezve azt.

\begin{tabular}{|l|l|}
\hline 1. fázis \\
\hline Átadó: irányító & Utód: nincs szerep \\
\hline
\end{tabular}

Handler (1989) folyamatos modellje alapján az utódlási folyamat kezdőpontja, amikor az utód még nem tagja a szervezetnek. Az alapító irányítja a céget. Az utódlás terve még nem született meg, potenciális utódjelöltje sincs még a vállalkozásnak. A vizsgált családi vállalkozások kezdeti és növekedési életszakaszára jellemző ez az időszak.

Az utód még gyermek, ismerkedik a vállalkozással, mint a szülő/szülők munkahelye. A vállalkozásokban az alapítók még nem tekintettek potenciális utódként egyik gyermekükre sem. A vállalkozások kezdeti időszakában az utódlás kérdésével nem foglalkoztak az alapítók. A IV. számú vállalkozás vezetőjében - ahol a gazdálkodási tevékenységnek voltak családi hagyományai - merült csak fel vágy, hogy szeretné, ha valamelyik gyermeke folytatná a munkáját. Ezt azonban nem határozták el. A potenciális utód kiválasztásával már elkezdődik egyfajta tanulási folyamat a vállalkozásokban végzett alkalmi munkavállalásokkal. A megismerésé, a tanulásé a föszerep. A vizsgált családi vállalkozásokban azonosítható ez a szakasz.

Ezek után az utód a vállalkozás alapjaival ismerkedik. Az utódok a vállalkozó családba való születésről és nevelkedésről úgy vélekedtek, hogy ekkor még nem fogalmazódott meg bennük az átvétel szándéka. A II. számú vállalkozás utódja inkább negatív tapasztalatokat szerzett ebben az időszakban. A vállalkozó édesapa nem tudott részt venni a családi életben, túlzottan a vállalkozásnak szentelte az idejét és a figyelmét. Így, ez a vállalkozói életforma az utód számára egyáltalán nem volt vonzó.

Majd kezdetlegesen vesz részt a gyerek a cég müködésében, részmunkaidőben vagy be-besegít esetleg nyári munkaként. Ebben a korban a tanulás az elsődleges tevékenység, továbbtanulási irányt a családi vállalkozásban betöltendő szerep motiválhatja. A vizsgált vállalkozások utódjai végeztek diákmunkát a cégekben. A pályaválasztásukban szempont volt a családi vállalkozásban hasznosítható tudás megszerzése, de az alapítók nem határozták meg a továbbtanulás konkrét irányát.

\begin{tabular}{|l|l|}
\hline 2. fázis \\
\hline Átadó: uralkodó & Utód: segitö \\
\hline
\end{tabular}

Az alapító a sikerre vitt vállalkozásban az „uralkodó”. Az utód segítő szerepben van, már belép a vállalkozásba. A funkcionális feladatok ellátása mellett megismeri a szervezet müködését.

A vizsgált vállalkozások közül az I.-II. számú vállalkozás van ebben a szakaszban. Az utódok meghatározott feladatkörben dolgoznak a vállalkozásban. Az I. számú vállalkozásban szakértő igazgatók irányítják az utódok munkáját, közvetlenül ök segítik a beilleszkedésüket és támogatják a tanulási folyamatot. A II. vállalkozásnál hiányzik az edukáció, az utód dolgozik a vállalkozásban, de sem az alapító, sem a középvezetői szint nem támogatja a szervezet egészének megismerését. Ekkor már teljes munkaidőben dolgozik az utód a cégnél, még nem vezetöként. Különböző munkakörökkel ismerkedik, vagy menedzseri pozícióban van, de nem ügyvezető még.

\begin{tabular}{|l|l|}
\hline 3. fázis \\
\hline Átadó: átruházó & Utód: menedzser \\
\hline
\end{tabular}

Az előző szakaszban az átadó és az utód már együtt dolgozik a vállalkozásban, de a közös vezetés és a felelősség egyre nagyobb részének átadása ekkor jelenik meg. Az előd az átruházó szerepébe lép és kezd a vállalkozásból kivonulni, az utód, a menedzseri feladatokat veszi át. Az előző szakaszok megalapozzák a bizalmat az átadásra, az átadó delegációs képessége nagy jelentőségü ebben a szakaszban. Ekkor történik a vezetői pozíció betöltése. Az előd még nem vonul vissza, sokszor ilyenkor még ő a tényleges vezető. A vizsgált vállalkozások közül a III. számú lépett be ebbe a szakaszba. A vállalkozásban már lezajlott a tanulási folyamat, az utód 
már a vezető feladatokból veszi ki a részét. A vállalkozás szervezeti felépítésében nincs középvezetői szint, ezért az alapító mellett helyezkedik el a szervezeti struktúrában.

\begin{tabular}{|l|l|}
\hline 4. fázis \\
\hline Átadó: tanácsadó & Utód: vezetö \\
\hline
\end{tabular}

Az átadás utolsó szakaszában az előd már, mint tanácsadó jelenik meg, aktívan nem vesz részt a vállalkozás müködtetésében, az utód vezeti a vállalkozást. A modell szerint az utódlás akkor fejeződik be, ha a vezetői szerepek és jogok mellett a tulajdonlás jogát is átadják a szervezetben. Az utódlás utolsó lépése jelenik meg ebben a fázisban. Ekkor tényleges cégvezetővé válik az utód és az előd teljesen kivonul a céges ügyekböl. A IV. számú vállalkozás jutott el ebbe a szakaszba az utódlási folyamatban. Az alapító már csak tanácsadóként van jelen a vállalkozásban.

\section{Az utódlási folyamat nehézségeinek összefoglalása}

Az esettanulmányok eredményeképpen azonosítottuk azokat a fóbb nehézségeket, amelyek az utódlási folyamatok során, vagy azt megelőzően felmerültek. A vállalkozások jelenlegi működésében meghatározó a vezető. A centralizált egyvonalas döntéshozatal, a lapos vállalati hierarchia, a szabályozatlan vagy csak részben szabályozott munkafolyamatok, a föként személyes koordinációs eszközök, túlterhelik a vezetőt, akinek információfeldolgozó képessége, tudása, ideje korlátozott és a megnövekedett szervezeti méretben elérte a határát.

A vállalati kultúra meghatározója a vezető, személye sokszor egyet jelen a vállalkozással. A vállalkozás vezetése informális kommunikációs csatornákon keresztül történik. A munkavállalók lojalitása is sokszor elsődlegesen a vezető felé irányul. A vállalkozó szakmai kompetenciái kiterjednek minden munkafolyamatra.

A családi fejlődésből adódóan nehézséget okoz a kettős vezetés rendszerének kialakítása, elválasztani az utód és az átadó szerepét a vezetésben. Ugyanakkor ehhez az is hozzájárul, hogy a tulajdonos-vezetők sok esetben ragaszkodnak a felépített tulajdonhoz, vagy magához a teljes vállalkozáshoz. Azonban ez a teher nemcsak az átadó oldalán jelenik meg, hanem az utódok oldalán is, hiszen bizonyos fokú megfelelési kényszer jelenhet meg velük szemben a teljesítésre és beilleszkedésre vonatkozóan, ami gyakran nemcsak az átadó felől nyomás, de a vállalkozás többi alkalmazottja felől is. Ezzel kapcsolatos kényszer vonatkozhat akár az utód edukációjára is, hiszen több esetben tapasztaltuk, hogy azt az igényt, hogy az átadó az utódlás előfeltételének érzi az utód tanulmányainak elvégzését. Ugyanakkor ez a nehézség hosszú távon előnyt is jelenthet a vállalkozások számára, hiszen számos kutatás bizonyította, hogy a hazai vállalkozások vezetői híján vannak a menedzsmentkompetenciáknak (Mosolygó et al., 2018; Noszkay, 2017), amelyek egy megfelelő képzés megtalálásával és elvégzésével akár az utódok által pótolhatók is lehetnének. A vállalkozás munkavállalói felé történő megfelelés ugyanakkor abban is megnyilvánulhat, hogy megfelelően elkerüljék az átadó és az utód közötti érdekütközéseket, azonban a személyes érdekek közötti határok megtalálása egy családi vállalkozás esetében jóval nehezebb, mint egy nem-családi vállalkozás esetén.

A vállalkozások vizsgálata során azt tapasztaltuk, hogy az utódlástervezés a családi utód megtalálásával kezdődik, vagyis ebben az esetben is megmutatkozik a vállalkozások informális és reaktív tervezési jellege. Ugyanakkor az is tapasztalható, hogy az utód megtalálásával az utóddal kapcsolatos elvárások nem tisztázódnak, amely hosszú távon az átadás-átvétel és a pszichológiai tulajdon elengedése során okozhat problémát a vállalkozások esetében. Ugyanakkor ezáltal az sem válik teljesen világossá, hogy az utód számára miképpen teremthető meg a belső motiváció, a vállalkozás iránti belső kötődés elérése. Jellemzően minden hasonló generációk közötti együttmüködési helyzetben, itt is felmerülhetnek generációs különbségekből adódó problémák, akár a motivációnál is.

A tulajdonlás fejlődése során elsődleges fontosságú, hogy a vezetői szerepek átadása mellett az átadó és az utód közötti tulajdonhoz kapcsolódó érdekeltség megfelelöen kiegyensúlyozott legyen. Azonban ezek a problémák elkerülhetők lehetnének a tulajdonátadás részleteinek lefektetésével az utódlási terv keretein belül.

A tulajdonlás során gondot okozhat a nem-tulajdonos utódok kompenzálása, például, ha az egyik testvér nem akar részt venni a vállalkozásban, az alapító az igazságosság elve alapján kompenzálni akarja és tulajdonrészt ad neki. Ugyanakkor fontos, hogy ha a testvérek tulajdonosként benn maradnak a cégben, de a müködésben nem vesznek részt, akkor a szavazati jogukkal ne korlátozzák a vezető testvérüket, például a vezető beruházni akar, a testvér több osztalékot stb., ezért érdemes végiggondolni a tulajdonos utódok és tulajdonos/vezető utódok döntési erejének súlyozását.

\section{Következtetések és diszkusszió}

A vizsgált vállalkozásoknál felmértük az utódlás jelenlegi helyzetét, megvizsgáltuk az adott helyzet fóbb jellemzőit, valamint összegyüjtöttük azokat a nehézségeket, amelyek felmerültek az utódlási folyamat során. Az első kutatási kérdés alapján a vizsgált családi vállalkozások Handler és Gersick et al. modellje alapján az utódlás 7. táblázatban leírt azonosított szakaszaiban vannak.

\begin{tabular}{|l|l|l|l|l|l|}
\hline $\begin{array}{l}\text { Vállalko- } \\
\text { zás }\end{array}$ & \multicolumn{1}{|c|}{ I. } & \multicolumn{1}{c|}{ II. } & \multicolumn{1}{c|}{ III. } & \multicolumn{1}{c|}{ IV. } & \multicolumn{1}{c|}{ V. } \\
\hline $\begin{array}{l}\text { Üzleti } \\
\text { fejlődés }\end{array}$ & érettség & érettség & érettség & érettség & $\begin{array}{l}\text { terjeszke- } \\
\text { dés }\end{array}$ \\
\hline $\begin{array}{l}\text { Családi } \\
\text { fejlődés }\end{array}$ & $\begin{array}{l}\text { közös } \\
\text { munka }\end{array}$ & $\begin{array}{l}\text { közös } \\
\text { munka }\end{array}$ & $\begin{array}{l}\text { közös } \\
\text { munka }\end{array}$ & $\begin{array}{l}\text { staféta } \\
\text { átadása }\end{array}$ & $\begin{array}{l}\text { belépés } \\
\text { az } \\
\text { üzletbe }\end{array}$ \\
\hline $\begin{array}{l}\text { Tulaj- } \\
\text { donlás } \\
\text { fejlődése }\end{array}$ & $\begin{array}{l}\text { testvéri } \\
\text { partner- }\end{array}$ & $\begin{array}{l}\text { tulajdo- } \\
\text { nos által } \\
\text { kontrol- } \\
\text { lált }\end{array}$ & $\begin{array}{l}\text { tulajdo- } \\
\text { nos által } \\
\text { kontrol- } \\
\text { lált }\end{array}$ & $\begin{array}{l}\text { tulajdo- } \\
\text { nos (utód) } \\
\text { által kont- } \\
\text { rollált }\end{array}$ & $\begin{array}{l}\text { tulajdo- } \\
\text { nos által } \\
\text { kontrol- } \\
\text { lált }\end{array}$ \\
\hline $\begin{array}{l}\text { Alapító } \\
\text { szerepe }\end{array}$ & uralkodó & uralkodó & $\begin{array}{l}\text { átruházó } \\
\text { tanácsadó }\end{array}$ & irányító \\
\hline $\begin{array}{l}\text { Utód } \\
\text { szerepe }\end{array}$ & segítő & segítő & $\begin{array}{l}\text { mene- } \\
\text { dzser }\end{array}$ & vezető & $\begin{array}{l}\text { nincs } \\
\text { szerep }\end{array}$ \\
\hline
\end{tabular}

7. táblázat A vizsgált vállalkozások utódlási állapota (saját szerkesztés) 
A vizsgált vállalkozások többsége az érettség fázisában van, ahol a családi fejlődésben a közös munka a jellemző, és a tulajdonlás még nagyrészt a tulajdonos-vezető által kontrollált. Gersick et al. (1997) szerint e fázisokban a legfőbb kihívást a tőkésítés, a tulajdonosi struktúra választása, a középidei átalakulás menedzselése és a fiatalabb generáció elkülönülése, valamint a stratégiai re-fókusz jelenti.

A gyakorlatban a Handler modell keretet ad az utódlási tervnek, a modellben meghatározott szakaszokhoz időintervallumok rendelhetők, így leírható az átadás folyamata. A fentiekben mintaként bemutatott utódlási terv is illeszkedik a modellhez, a 2-3-4. lépés szerepel a tervben. A vizsgált vállalkozások mindegyike egyértelmüen besorolható a modell egy-egy fázisába. A vállalkozások vezetői folyamatként tekintenek az átadásra. A vezetői szerepek átadása a vizsgált családi vállalkozásokban olyan folyamaton megy keresztül, amelynek során a felelősség és az irányítás fokozatosan kerül át az átadóról az utódra.

A Gersick et al. modell alkalmazása a családi vállalkozás helyzetének feltérképezésére ad lehetőséget. Az utódlás tervezésénél elengedhetetlen egy pillanatkép készítése a vállalkozási/családi/tulajdonosi viszonyok helyzetéröl. A három dimenzió szoros összefüggésben van, így a vállalkozás utódlási tervét is meghatározzák. Például a család tengelyen látható az átadó/utód életkora, ami egyértelmüen definiálja az utódlási folyamat kezdetét. A családi életben megjelenő krízisek (pl. válás) is változtathatnak az utódlási terven stb.

A két modellt össze is kapcsolhatjuk a gyakorlatban: a handleri modell lépései szerint megalkotott utódlási tervhez a szakaszok kezdetén felállíthatunk egy helyzetképet a vállalkozás/család/tulajdon állapotáról. Ennek segítségével ellenőrizhetjük a megvalósítás realitását, illetve elvégezhetjük a szükséges módosításokat.

Az általunk azonosított fejlődési fázisokhoz kapcsolódó főbb nehézségeket a 8. táblázat foglalja össze.

A vizsgált vállalkozásokban feltárt nehézségek részben megerősítik az eddig szakirodalomban feltárt hazai vállalkozások nehézségeit, azonban számos újdonságot is jelentő problémára is felhívták a figyelmet. Több hazai kutatás is bizonyította, hogy a hazai családi vállalkozások mükö- dési folyamatai szabályozatlanok, szervezeti rendszerük egyvonalas lineáris, a formalizált müködés csak lassan és fokozatosan megy végbe náluk (Noszkay, 2007; Csákné, 2012; Salamonné, 2006). A kommunikációs problémák nemcsak az utódlásban okoznak nehézséget, hanem általánosságban a vállalkozás müködésében, a kommunikáció fejlesztése folyamatos feladat. A vállalkozások gyakorlatára jellemző a „kézivezérlés” (Noszkay, 2017) és az egyszemélyi döntéshozatal, ezért a több szempontúság hiánya a döntésekben jellemzővé válhat. A túlterhelt felső vezetés és a tulajdonos-menedzser dominancia sokszor oda vezet, hogy a tulajdonos-vezetök nehezen engedik ki a kezükböl a hatalmat, valamint sokszor nehézséget okoz a család és a vállalkozás érdekeinek kettéválasztása (Csákné, 2012; Salamonné, 2006; Bogáth, 2014). Az utód folyamatos bevonása, szerepvállalása az üzleti folyamatokba feloldaná a többszempontúság kérdését, azonban ehhez szükséges jó előre tisztázni az utóddal kapcsolatos elvárásokat is. A teljesítmény folyamatos értékelése - mind a pozitívumok, mind a negatívumok felszínre hozása - megerősíti az utódot, önbizalmat ad neki, önbizalmát/kompetenciáját növeli. Ugyanakkor az is jól látható az esettanulmányok alapján, hogy az utódlás tervezésének hiánya más jellegü problémákat is magával hoz. Az utóddal szemben támasztott elvárások, akár az edukációjára, vagy a belső motiváció megtalálására vonatkozóan elsődleges lehet az elengedést illetően. Egy jól felépített utódlási folyamat, ami az előzőeket részletesen tárgyalja, valamint a tulajdonlással kapcsolatos átadási részleteket is, számos nehézségtől megóvná az utódlásban érintett vállalkozások szereplőit.

A vizsgált családi vállalkozásoknál megfigyelhetö, hogy a családon belüli utódlás esetén potenciális utódként csak arra a gyermekre tekintenek, akinek van ambíciója, kompetenciája a vállalkozás átvételére. A családi cég utódra való kényszerítése, eleve elrendelése a vizsgált vállalkozásoknál nem jellemző. Az átadásnál fontosnak tartják, hogy az utód megismerje a vállalkozásban zajló folyamatokat és részt is vegyen ezekben, mert ezáltal tud valódi tapasztalatokat szerezni. Az utód vállalkozásba bevonása során kiemelten fontos helyzetének meghatározása, tanítása

\begin{tabular}{|c|c|c|}
\hline $\begin{array}{c}\text { Üzleti fejlődésből adódó } \\
\text { nehézségek: }\end{array}$ & $\begin{array}{c}\text { Családi fejlődésből adódó } \\
\text { nehézségek: }\end{array}$ & Tulajdonlás fejlődése: \\
\hline $\begin{array}{l}\text { - Kommunikációs problémák és } \\
\text { nehézkes horizontális koordináció } \\
\text { - Több szempontúság hiánya } \\
\text { a döntésekben } \\
\text { - Felelősségi és teljesítményértékelési } \\
\text { problémák } \\
\text { - Túlterhelt felső vezető: személyes } \\
\text { jelenlét szükséglet, } \\
\text { nehéz helyettesíthetőség } \\
\text { - Időigényes verbális kommunikáció } \\
\text { - A vezető szerep- és feladathalmozása } \\
\text { a munkatársakat demotiválja és passzív } \\
\text { befogadókká teszi }\end{array}$ & $\begin{array}{l}\text { - Kettős vezetés kialakítása } \\
\text { - Pszichológiai tulajdonlás kérdése } \\
\text { - Utódok megfelelési kényszer, } \\
\text { „tulajdonos”-i teher érzése } \\
\text { - Utód edukációja, mint feltétel és elvárás } \\
\text { - Családi összefonódások, } \\
\text { érdekütközések elkülönítése } \\
\text { - Potenciális utód megtalálásával } \\
\text { kezdődik csak a tervezés } \\
\text { - Utóddal kapcsolatos elvárások } \\
\text { megfogalmazásának hiánya } \\
\text { - Utód belső motivációjának } \\
\text { megteremtése } \\
\text { - Generációs nézetkülönbségek } \\
\text { összeegyeztetése }\end{array}$ & $\begin{array}{l}\text { - Tulajdonosi érdekeltség és utódok } \\
\text { érdekeltségének kiegyensúlyozása } \\
\text { - Utódlási tervben a tulajdonátadási } \\
\text { részletek lefektetésének hiánya } \\
\text { - Nem tulajdonos utódok kompenzálása } \\
\text { - Tulajdonos utódok és tulajdonos/vezető } \\
\text { utódok döntési erejének súlyozása }\end{array}$ \\
\hline
\end{tabular}

8. táblázat A vizsgált vállalkozások utódlási nehézségei 
és motiválása. Az átadó helyzetét megkönnyíti, ha rendelkezik a vállalkozáson kívül egyéb vagyonnal, jövedelemmel. Amennyiben a megélhetése biztosított, bátrabban adja át a felelősséget, az irányítást és a tulajdont is. Azonban ez a tényező nemcsak az átadó, de az utód helyzetére is hatással van. Tapasztalataink szerint, ha az utód nem rendelkezik valódi jogkörökkel, nincs ráruházva a felelősség akkor motiválatlan lesz, ,nem találja a helyét”. Az utód számára elengedhetetlen, hogy érezze a teljes körü bizalmat, támogatást, és érezze a felelősség súlyát, mert csak így képes azzal az odaadással, figyelemmel és fegyelemmel átvenni a vállalkozást, amit egy családi vállalkozás alapítója elvár. Ez a helyzet tulajdonképpen úgy müködik, mint egy spirál: ha az utód nem kapja meg a teljes bizalmat, nem fogja magáénak tekinteni a vállalkozást, ezáltal nem vesz részt benne olyan intenzitással, ami további nehézséget, bizonytalanságot gerjeszt az átadónál a valódi átadással kapcsolatban. Ez a bizalmatlanság, bizonytalanság tovább távolítja az alapítót és az utódot is, aminek eredményeként a vállalkozás átadása kudarcba fullad. Az alapítónak döntést kell hozni az átadásról az utódlási folyamat elején és ahhoz következetesen tartania magát.

A pszichológiai utódlás nehézsége csak akkor van jelen, ha az alapító nem hozott valódi döntést. A potenciális utód megtalálása - akivel szemben teljesülnek az átadó elvárásai - megkönnyíti az elengedést. A vállalkozási tevékenység befejezését követő tevékenységtervek, célkitüzések szintén segítik az átadást. Valamint a felhalmozott különvagyon - jövőbeni megélhetési biztonság - is elősegíti a sikeres átadást. Természetesen ennek a folyamatnak a fordítottját nem garantálja az alapító számára rendelkezésre álló független jövedelem, azonban azt gondoljuk, hogy mindenképpen segítő, az átadást motiváló szerepe megkérdőjelezhetetlen.

Az utód érdeklődésének felkeltése az alapító feladata. Az átadó saját életformájával, értékrendjével, egyéb emberi tulajdonságaival történő példamutatás motiválja az átvevőt. Az utódot lehet érdekeltté is tenni külső motivációs eszközökkel (adó/foglalkoztatási/hitel kedvezményekkel).

Az új tulajdonosi szerkezet meghatározása a tulajdonrészek (ezáltal a szavazati arányok) megfelelő súlyozásával történik. A célja a felosztásnak a vezető tulajdonos döntési lehetőségének biztosítása és a nem vezető tulajdonosok anyagi részesedése a családi vállalkozásból. A nehézségek/jövőbeli konfliktusok megoldhatók/elkerülhetők a tulajdonosi arányok pontos meghatározásával és dokumentálásával.

A családi vállalkozások, társadalmi és gazdasági szerepe vitathatatlan Magyarországon is. Egyedi jellemzőik, amik megkülönböztetik a nem családi cégektől előnyük és hátrányuk is lehet. A családi kisvállalkozások szervezeti és vezetési rendszerére leginkább az egyszerü szervezeti jellemzők illenek. A fejlődés, növekedés során felmerül a kérdés, hogy mennyire formalizálja a rendszereit úgy, hogy a családi kisvállalkozási értékek, előnyök megmaradjanak.

A vállalati életciklus-elméletek segítséget adnak a vállalkozásoknak, meghatározni, hogy melyik fejlődési fázisban vannak jelenleg, valamint útmutatót nyújtanak a továbblépéshez, a növekedés lehetőségéhez. A modellek meghatározzák a fázisok jellemző szervezeti és vezetési tulajdonságait és a továbblépéshez szükséges változtatási feladatokat. Az életpályamodellek az utódlás tervezését és az utódlási terv lépéseinek meghatározását is támogatják.

Az utódlás lehetőséget teremt a családi vállalkozások számára a megújulásra, a további növekedésre. Az utód lendülete, új képességei, az életkorából fakadó rugalmasabb szemléletmódja kihasználandó érték, ami gazdagítja ezeket a vállalkozásokat. Minél több jó gyakorlat felkutatása, bemutatása, elemzése mintaként szolgálhat a többi családi vállalkozás számára működésük további sikeres fenntartására.

A vállalkozás (V.) utódlási tervezését segítette a kutatásban részt vevő többi vállalkozás gyakorlata, az interjú során megfogalmazott kérdések lehetőséget adtak a válaszok megfogalmazására. A bemutatott utódlási modellek megvilágították az átadás folyamatát és a családi vállalkozások három dimenziójának kapcsolatát és összefüggéseit. „Most még biztos, hogy nem kezdtem volna el komolyan foglalkozni az utódlás tervezésével, valószínủleg erre akkor került volna sor, amikor az utód befejezi a tanulmányait. A terv körvonalai: a célok, hogy mit szeretnék a jövőben, már megfogalmazódtak bennem. Az ezek eléréséhez vezető út részleteivel, a felmerülő nehézségekkel, valamint az utódlás folyamatában rejlő lehetőségekkel azonban nem foglalkoztam érdemben. A kutatásban bemutatott vállalkozások gyakorlatában vannak olyan dolgok, amiket nem csinálnék, túllépnék rajta, pedig fontosak lehetnek. Segítségemre voltak a minták, hogy átlássam a folyamat időigényességét, különösen akkor, ha a vezető egyedül van.” - jelezte az V. vállalkozás tulajdonosa.

A vállalkozások átadásában a kezdő lépés a cégvezetők figyelmének felhívása. A magyarországi kisvállalkozások többnyire a közmédiában találkoznak néhány cikkel a témával kapcsolatban, amelyek kimerülnek a probléma felvillantásában és a folyamat fontosságának és nehézségének hangsúlyozásában. Megoldási lehetőségként tanácsadók/ szakértők bevonásának lehetőségét adják. A magyarországi kis családi vállalkozásokra - itt a néhány főt foglalkoztató mikrovállalkozásokra gondolunk - nem jellemző a külső szakértők bevonására sem a bizalom, sem pedig az ehhez szükséges anyagi fedezet megléte. A bizalom hiánya abból az általános vállalkozói szemléletből ered, hogy ezeknek a cégeknek a vezetői a saját döntéseikben bíznak, ragaszkodnak a szabadságukhoz, önállóságukhoz, hiszen ezért is választották az alkalmazotti lét helyett az önálló vállalkozás indítását. Ezekhez a jogaikhoz - sikeres vállalkozás esetén igazolt értékteremtésükhöz - ragaszkodnak. Az utódlási modellek a kisvállalkozások átadásának kezdő lépéseiben nyújthatnak segítséget: elindíthatják a vállalkozásokat a tervezés útján. Véleményünk szerint, mindkét modell alkalmas arra, hogy e vállalkozások vezetőinek kézzel fogható keretet nyújtsanak az utódlás megvalósításához. A modellekhez kapcsolt kérdések és az ezekre adott válaszok segítenek a vállalkozás helyzetének elemzéséhez, a célok és lehetőségek meghatározásához. Szakértők bevonása a következő lépés lehet, miután a vállalkozó meghozta a saját döntéseit, megfogalmazta a kérdéseit és realizálta a korlátait. Pénzügyi/ vállalatvezetési/jogi tanácsadók iránymutatásait ekkor már hajlandók a vállalkozók integrálni a terveikbe. 
A „Hogyan tovább családi vállalkozások?” kérdést fel kell tenni a vezetőknek. Az információk közvetítéséhez a vállalkozások közvetlen környezetében lévő szervezetek/ intézmények alkalmasak leginkább: kamarák, pénzintézetek a cégek könyvelését/adótanácsadását végző vállalkozások. A könyvelök különös bizalmi viszonyban állnak ezekkel a kis cégekkel, ismerik a vállalkozót, a családját, betekintésük van a vállalkozás pénzügyi, gazdálkodási adataiba és ismerik a tulajdonosi viszonyokat is. A kamarák szolgáltatási feladatai közé szervesen beilleszthető lenne az utódlással kapcsolatos érdemi tájékoztatás. Az Európai Bizottság által közzétett útmutató is tartalmazza a képzés és mentorálás fontosságát. "A tagállamoknak támogatniuk vagy szervezniük kell olyan tevékenységeket (például a kereskedelmi kamarák bevonásával), amelyek tudatosítják a tulajdonosokban, hogy kellő időben elő kell készíteni a vállalkozás átadását. A tagállamoknak különösen az olyan közvetlen megszólítást érdemes megfontolniuk, mint például egy bizonyos kor feletti üzlettulajdonosokhoz személyre szólóan intézett levél. Ezenkívül a kisvállalkozások fontosabb partnereit (adótanácsadókat, könyvelöket, bankokat stb.) is be kell vonni a figyelemfelkeltő kampányokba" (European Commission, 2012, p. 22.). Az útmutatóban közzétett felmérés szerint Magyarország ilyen jellegü tevékenységéről nincs adat.

A kutatásban szereplö vállalkozások közül egy esetben (IV.) már sikeresen lezárult az átadás folyamata. Az interjúalanyok elmondása szerint a sikerben hangsúlyos volt az átadás külső motiválása, ami egy minisztériumi pályázatban nyilvánult meg. A magyarországi kisvállalkozásokra jellemző a fejlesztési pályázatokon való részvétel aktivitása. A kutatásban szereplő vállalkozások mindegyike több alkalommal is megragadta ezeket a fejlesztési lehetőségeket. A vállalkozói szemlélet magába foglalja a lehetőségek megragadását és kihasználását. A hazai kisvállalkozások még nincsenek olyan érettségi szinten, hogy külső motiválás nélkül üzleti terveket készítsenek, hosszú távra tervezzenek, így szükséges, hogy "üzletet” lássanak egy-egy feladatban. Ez az attitűd, az átadás szempontjából sem hagyható figyelmen kívül. A külső motiválási eszközök: pályázatok, adó- és járulékkedvezmények előmozdíthatják sok vállalkozás sikeres átadását. Ezek az eszközök az utódok érdekeltté tételében is alkalmazhatók, a fent említett Bizottsági útmutató is tartalmazza, hogy az új vállalkozások ösztönzésének alternatívája kell, hogy legyen a meglévő vállalkozások átvétele, ami hasonló lehetőségek igénybevételét jelenti a leendő utódok számára. A felsőoktatási hallgatók körében végzett kutatás (Reisinger, 2013) szerint a karrierválasztásban a saját vállalkozás alapításának szándéka jóval meghaladja a meglévő vállalkozás folytatásának tervét. Természetesen ennek összetett okai vannak, azonban az átvétel, mint egyenrangú alternatíva, ösztönző hatású lehet.

\section{Kutatás korlátai és kutatási jövőkép}

Kutatásunk céljához igazodva elsődleges volt feltárni a vizsgált vállalkozások utódlásával kapcsolatos nehézségeket, azonban több a kutatást érintő korláttal is számolni kell. Egyrészről a vizsgálatba bevont minta számossága nem feltételez általánosíthatóságot, csupán kezdeti felté- telezések és a jövőbeni kutatási kiindulópontok meghatározásához lehet elégséges. A vizsgálati minta azonban jó alkalmat nyújtott arra, hogy a szakirodalomban előzetesen bemutatott eddigi feltételezésekre, valamint kutatási eredményekre reagálni, továbbá azokat kiegészíteni tudjuk. Ezért is lenne fontos a jövőben a trianguláció elvét követve több adatforrásra támaszkodó kutatást elvégezni mind kvalitatív, mind pedig kvantitatív adatokat gyüjtve.

Másrészről a félig strukturált interjú esetén a kérdések irányítottak és ezeknek így van befolyásoló hatásuk az interjúalanyra, valamint a kérdező személye, a beszélgetés során önkéntelenül kinyilvánított véleménye is torzíthatja valamelyest a kutatás eredményeit.

A mintaválasztás a vállalkozói környezetünkben lévő cégek közül történt, akikről ismert volt, hogy érintettek az utódlás témájában. Úgy tünhet, hogy a kutatásba bevont családi cégek számára nem okoz különösebb gondot az utódlás. Ez nem így van, de a hosszú távú sikeres müködés már feltételez egyfajta tervezettséget, már van potenciális utód, tehát egy-két nehézség már valóban megoldott számukra. Azonban sikerről még csak egy esetben beszélhetünk.

\section{Felhasznált irodalom}

Adizes (1992): Vállalatok életciklusai. Budapest: HVG

Barnes, L. B. - Hershon, S. A. (1976): Transferring power in the family business. Harvard Business Review, Július/Augusztus, p. 105-114.

Bogdány E. (2014): Átadni tudni kell! Vezetői szerep átadás a hazai kis- és középvállalkozásokban. PhD-értekezés. Veszprém: Pannon Egyetem

Bogdány E. - Csizmadia T. (2017): A kis- és középvállalkozások vezetésének változása az utódlás aspektusából. In: Vilmányi Márton - Kazár Klára (szerk.) (2017): Menedzsment innovációk az üzleti és a nonbusiness szférákban. Szeged: SZTE Gazdaságtudományi Kar, 38-57. o.

Churchill, N. C. - Lewis, V. L. (1983): The five stages of small business growth. Harvard Business Review, $61 / 3$, p. $30-50$.

Churchill, N. C. - Hatten, K. J. (1987): Non-market based transfers of wealth and power: A research framework for family businesses. American Journal of Small Business, 11/3, p. 51-64.

Csákné Filep J. (2012): Családi vállalkozások - Fókuszban az utódlás. http://phd.lib.uni-corvinus.hu/660/1/ Csakne_Filep_Judit_dhu.pdf letöltve:2018.03.05.

Csizmadia P. - Makó Cs. - Heidrich B. (2016): Managing succession and knowledge transfer in family businesses: lessons from a comparative research. Vezetéstudomány, XLVII. évf. 11. sz., p. 59-69.

Danco, L. A. (1982): Beyond survival: A business owner's guide for success, Cleveland, $\mathrm{OH}$ : University Press

Davis, J. A. - Tagiuri, R. (1989): The influence of life stage on father-son work relationships in family companies. Family Business Review, 2(1), p. 47-74.

Devins, D. - Jones, B. (2016): Strategy for succession in family owned small businesses as a wicked problem to be tamed. Vezetéstudomány, XLVII. évf. 11., p. 4-15.

European Commision (2012): A vállalkozások átadásának megkönnyítése. Útmutató-sorozat: A KKV-fejlesztési 
politika támogatása a strukturális alapokból. Európai Unió, 2012 Printed in Belgium

European Commission Enterprise and Indusrty Directorate-General (2009), Final report of the expert group, overview of family-business-relevant issues: research, networks, policy measures and existing studies. http://ec.europa.eu/DocsRoom/documents/10388/attachments/1/translations letöltve: 2017.11.14

Friedman, S. D. (1986): Succession systems in large corporations: Characteristics and correlates of performance. Human Resource Management, 25(2), p. 191-213.

Gersick, K. E. - Davis, J. A. - McCollom Hampton, M. Lansberg, I. (1997): Generation to generation: Life cycles of the family business. Boston: Harvard Business School Press, p. 2-31, 70-71

Greiner, L. (1998): Evolution and Revolution as Organisations Grow. Harvard Business Review, 5-6. sz., p. 65-87.

Handler, W. C. (1990): Succession in family firms: A mutual role adjustment between entrepreneur and nextgeneration family members. Entrepreneurship Theory and Practice, $15 / 1$, p. 37-51.

Handler, W. C. (1989): Methodological issues and considerations in studying family businesses. Family Business Review, 2/3, p. 257-276.

Harvey, M. - Evans, R. E. (1995): Life After Succession in the Family Business: Is It Really the End of Problems? Family Business Review, 8/1, p. 3-16.

Heidrich B. - Németh K. - Nick, Ch. (2016): Running in the family - paternalism and familiness in the development of family businesses. Vezetéstudomány, XLVII. évf. 11. sz., p. 70-82.

Karmazin Gy. - Gál I. (2016): Hazai logisztikai családi vállalkozások generációváltásának gyakorlata és hatása a vállalatok versenyképességére Versenyképességi tényezők a 21. században. Gödöllő: Szent István Egyetem Gazdaság- és Társadalomtudományi Kar, Üzleti Tudományok Intézete, Tevékenység-menedzsment és Logisztika Tanszék Tudományos közleményei

Kása R. - Radácsi L. - Timár G. - Zsigmond Sz. (2018): Családi vállalkozások mentorálása. Working paper series. Issue $5 / 6$

Kása R. - Radácsi L. - Csákné Filep J. (2018): Családi vállalkozások Magyarországon. Working paper series. 4-2017/8

Keating, N. C. - Little, H. M. (1997): Choosing the successor in New Zealand family farms. Family Business Review, 10(2), p. 157-171.

Konczosné Szombathelyi M. (2014): Családi vállalkozások generációváltásának kockázata. Győr: Széchenyi István Egyetem, http://kgk.sze.hu/images/doku-
mentumok/kautzkiadvany2014/KSZM.pdf letöltve: 2017.11.19

Longenecker, J. G. - Schoen, J. E. (1978): Management succession in the family business. Journal of Small Business Management, 16/ 3, p. 1-6.

Makó Cs. - Csizmadia P. - Heidrich B. (2016): Succession in the family business: need to transfer the 'socioemotional wealth’ (sew). Vezetéstudomány, XLVII. évf. 11. szám, p. 16-28.

Mandl I. (2008): Overview of family businesses relevant issues, Final report. Vienna: KMU Forschung Austria

McGivern, C. (1989): The dynamics of management succession: a model of chief executive succession in the small family firm. Family Business Review, 2, p. 401-11.

Mosolygó Á. - Csákné Filep K. J. - Heidrich B. (2018): Do first swallows make a summer? - on the readiness and maturity of successors of family businesses in Hungary. Working paper series. Issue 6, 2018/1

Nagy A. Sz. - TobakJ. (2017): Családi vállalkozások vezetési és utódlási kérdései. Taylor: Gazdálkodás- és Szervezéstudományi Folyóirat, 2017/2. szám IX. évfolyam, p. 188-196.

Noszkay E. (2017): Tapasztalatok a családi vállalkozások átörökítésének dilemmái kapcsán. Vezetéstudomány, XLVIII. évf. 2017. 6-7. szám, p. 64 -72.

Pfeffer, J. - Salancik, G. R. (2003): The external control of organizations: A resource dependence perspective. New York: Harper \& Row

Quinn, R. E. - Cameron, K. S. (1983): Organizational Lifecycles and Shifting Criteria of Effectiveness: Some Preliminary Evidence, Management Science, 29, p. 33-51.

Reisinger A. (2013): Családi vállalkozás folytatásának tervei a felsőoktatási hallgatók körében. Vezetéstudomány, XLIV. évf. 2013. 7-8. szám, p. 41-50.

Salamonné Huszty A. (2006): Magyarországi kis- és középvállalkozások életútjának modellezése. Competitio, 5. évf. 1. sz., p. 51-68.

Stavrou, E. T. - Swiercz, P. M. (1998): Securing the future of the family enterprise: a model of offspring intentions to join. Entrepreneurship: Theory and Practice, 23/2, p. 19-39.

Vágány J. - Fenyvesi É. - Kárpátiné Daróczi J. (2016): Sikeres vállalkozás és ami mögötte van. Gradus, Vol 3, No 1., p. 506-511.

Vecsenyi J. (2009): Kisvállalkozások indítása és működtetése. Budapest: Perfekt

Ward, J. L. (1991): Business Business First or Family First? Use the Telephone the Right Way When Making Sales Calls. ASPA Turf News: May/June

Yin, R. K. (2009): Case study research: Design and methods (4th ed.). Thousand Oaks, Ca: Sage 